\title{
Hepatic changes in mice chronically infected with Helicobacter trogontum
}

\author{
S.B. Moura ${ }^{1}$ \\ D.M.M. Queiroz ${ }^{3}$ \\ G.A. Rocha ${ }^{3}$ \\ L.B. Comunian ${ }^{1}$ \\ and D.C. Cara ${ }^{2}$
}

Departamentos de ${ }^{1}$ Microbiologia and ${ }^{2}$ Patologia, Instituto de Ciências Biológicas, and ${ }^{3}$ Laboratório de Pesquisa em Bacteriologia, Faculdade de Medicina, Universidade Federal de Minas Gerais, Belo Horizonte, MG, Brasil

\section{Correspondence \\ S.B. Moura \\ Departamento de Microbiologia ICB, UFMG \\ Av. Antônio Carlos, 6627 \\ Campus Pampulha \\ 31270-901 Belo Horizonte, MG \\ Brasil \\ Fax: +55-31-3499-2730 \\ E-mail: sbmoura@icb.ufmg.br}

Research supported by $\mathrm{CNPq}$ and $\mathrm{PRPq} / \mathrm{UFMG}$, Brazil.

Received August 29, 2002

Accepted June 3, 2003

\begin{abstract}
We infected NIH germ-free female mice with Helicobacter trogontum, a recently described intestinal bacterium of rats, in order to study the lesions it induced in the liver of this host. Fifteen mice were challenged with a single dose of $H$. trogontum (test group) and killed 6, 12 and 18 months after inoculation (5 animals/group). Nine animals were challenged with $0.85 \%$ saline alone (control group) and killed at the same times. Fragments from the liver, cecum and colon were obtained for microbiologic and histologic examination. Stool samples were also collected. H. trogontum was detected in the cecum, colon and/or stool samples of all test mice. As expected, the bacterium was not isolated from any specimen obtained from the control animals. On the other hand, although we could not cultivate the bacterium from the liver, 13 test animals (86.7\%) presented histological changes in this organ. The 6-month group presented infiltration of mononuclear and polymorphonuclear cells in the hepatic parenchyma and the two other groups presented foci of mononuclear cells. The results suggest that $H$. trogontum can elicit a hepatic inflammatory response in mice since the only difference between control and test animals was the presence of $H$. trogontum in the latter. This result, together with the growing number of related reports in the literature, reinforces the possible role of Helicobacter infection in the pathogenesis of hepatobiliary diseases.
\end{abstract}

The recognition of Helicobacter pylori as a cause of chronic gastritis and peptic ulcers in humans (1) has led to an increased interest in the study of similar bacteria that colonize the gastrointestinal tract of animals (2). As a result, many new Helicobacter species have been described and linked to diverse diseases such as gastritis, peptic ulcer, hepatitis and enterocolitis in a wide range of animals (2-5). Thereafter, natural and experimental infections with Helicobacter sp
Key words - Helicobacter

- Helicobacter trogontum

- Animal model

- Liver

- Mice have been performed in animals not only for the purpose of comparing the infection with that of $H$. pylori in man, but also because of the growing recognition of the role of the bacterium in disease outbreaks in colonies of laboratory animals $(2,6)$.

An example of a species that has been extensively studied is $H$. hepaticus. The bacterium was isolated from the liver of mice serving as control in a long-term chemical carcinogenesis assay, which showed high incidence of 
chronic active hepatitis and liver tumors (7). After that, it was found that $H$. hepaticus infection is highly prevalent in commercial mouse colonies $(3,8)$. The bacterium persistently colonizes the colon and cecum of the animals and can elicit hepatitis and liver tumors in some susceptible inbred strains such as $\mathrm{A} / \mathrm{JCr}$ and $\mathrm{B} 6 \mathrm{C} 3 \mathrm{~F} 1$ mice $(9,10)$.

In 1996, we described a new Helicobacter species, $H$. trogontum, that colonizes the colonic mucosa of rats (5). Based on $16 \mathrm{~S}$ rRNA sequence analysis data, this species is closely related to $H$. hepaticus $(97 \%$ sequence similarity). In a recent study in which we infected germ-free mice with $H$. trogontum, we observed in the liver of 2 of 8 animals with one and six weeks of infection the presence of small focal inflammatory cell infiltration resembling the first stage of infection described in the liver of mice infected with $H$. hepaticus (11). Therefore, we decided to infect mice with $H$. trogontum for a longer period of time to study eventual liver lesions.

The type culture of $H$. trogontum (ATCC 700114) was grown on 10\% sheep blood agar for 3 days at $37^{\circ} \mathrm{C}$ under microaerophilic conditions. The bacteria were harvested and suspended in $0.85 \%$ saline to obtain an inoculum of $10^{9}$ cells $/ \mathrm{ml}$ and 100 $\mu l$ of the suspension was used for mouse inoculation by gastric intubation. The suspended bacteria were observed by phase contrast microscopy for motility before and after inoculation to test viability.

Twenty-four 4-week-old NIH germ-free female mice (Taconic, Germantown, NY, USA) reared in Trexler type isolators at the Laboratório de Gnotobiologia, Instituto de Ciências Biológicas/UFMG, Brazil, were used in this study. Fifteen mice were orally challenged with the $H$. trogontum inoculum (test group) and nine animals received $0.85 \%$ saline alone (control group). After inoculation, test and control mice were taken from the isolators and kept under the same conditions in separate open cages and also manipulated sepa- rately with sterile gloves in different rooms. The animals had free access to an autoclaved pelleted diet and sterile water.

Groups of five test animals were killed by spinal dislocation 6,12 and 18 months after inoculation. Groups of three control animals were also killed at the same times. Liver fragments were aseptically removed for histologic and microbiologic examination. Stool samples and fragments from the cecum and colon were also taken to determine if the animals were successfully colonized by $H$. trogontum.

For histologic examination, fragments of the liver, cecum and colon were fixed in $10 \%$ formalin, dehydrated through graded alcohols to xylol and embedded in paraffin. Sections of $4 \mu \mathrm{m}$ from each region were stained with hematoxylin and eosin for histologic examination. The slides were coded to eliminate observer bias and examined by one pathologist.

For microbiologic tests, liver fragments were separately homogenized with a sterile grinder and inoculated into 10\% sheep blood agar and Belo Horizonte medium (BHM) plates (12). The plates were then incubated under microaerophilic conditions at $37^{\circ} \mathrm{C}$ for up to 10 days. Fragments from the cecum, colon and stool samples were obtained for the urease test (13) and for culture in BHM under the same conditions as described above. An animal was considered to be $H$. trogontum-positive when the urease test was positive or when the bacterium was isolated from the cecum, colon or stool samples.

The urease test was negative and no Helicobacter species were isolated from any specimen obtained from the control animals. This result shows that germ-free mice reared in open cages can be maintained free of Helicobacter species for at least 18 months when bedding, food and water are sterilized and the groups of animals are manipulated separately with sterile gloves.

The test group was successfully infected with only a single dose of $H$. trogontum and the infection persisted for up to 18 months, 
as shown by the isolation of $H$. trogontum and/or the positive urease test in the cecum, colon or stool samples of all test animals. $H$. trogontum colonies were usually seen after 5 to 7 days of incubation as thin spreading films and, sometimes, as punctiform colonies that were strongly urease positive and produced catalase and oxidase (5). Under an oil immersion lens, after Gram staining the bacteria were seen as fusiform to slightly spiral Gram-negative cells.

The histology of the cecal and colonic mucosa of the test animals did not differ from control and was characterized by mild infiltration of mononuclear cells in the lamina propria. Similar features have been reported in immunocompetent rodents colonized by Helicobacter species. Conversely, SCID mice infected with bacteria closely related to $H$. trogontum such as $H$. hepaticus and $H$. bilis develop chronic colitis $(2,14,15)$. It would be of interest to investigate if $H$. trogontum can also cause inflammatory bowel disease in immunocompromised rodents.

H. trogontum was not cultivated from the liver of the control group and, as expected, no histologic or macroscopic alterations were observed in the hepatic parenchyma of the animals at any time point examined. In contrast, although $H$. trogontum was not isolated from the hepatic tissue of the test mice, histologic changes were observed in the liver of $13(86.7 \%)$ animals of this group. Histologic alterations were seen in all animals of the 6- and 12-month-infected groups and in three of the 18-month group. The lesions were characterized by foci of mononuclear and polymorphonuclear cell infiltrates and focal hepatocellular necrosis that were distributed in the hepatic parenchyma around the central lobular veins and portal triads. This histologic pattern of liver lesion resembles that observed in human beings with nonspecific reactive hepatitis caused by systemic infectious or neoplastic diseases (16). It is also described in mice with 10 to 28 weeks of $H$. hepaticus infection (17) as well as in dogs infected with $H$. canis (18). The inflammation in the liver of the 6-month test group was more prominent and extensive, with the presence of both mononuclear and polymorphonuclear cells (Figure 1A) and, after 12 months of infection, the infiltrates became less intense and were composed primarily of mononuclear cells (Figure 1B).
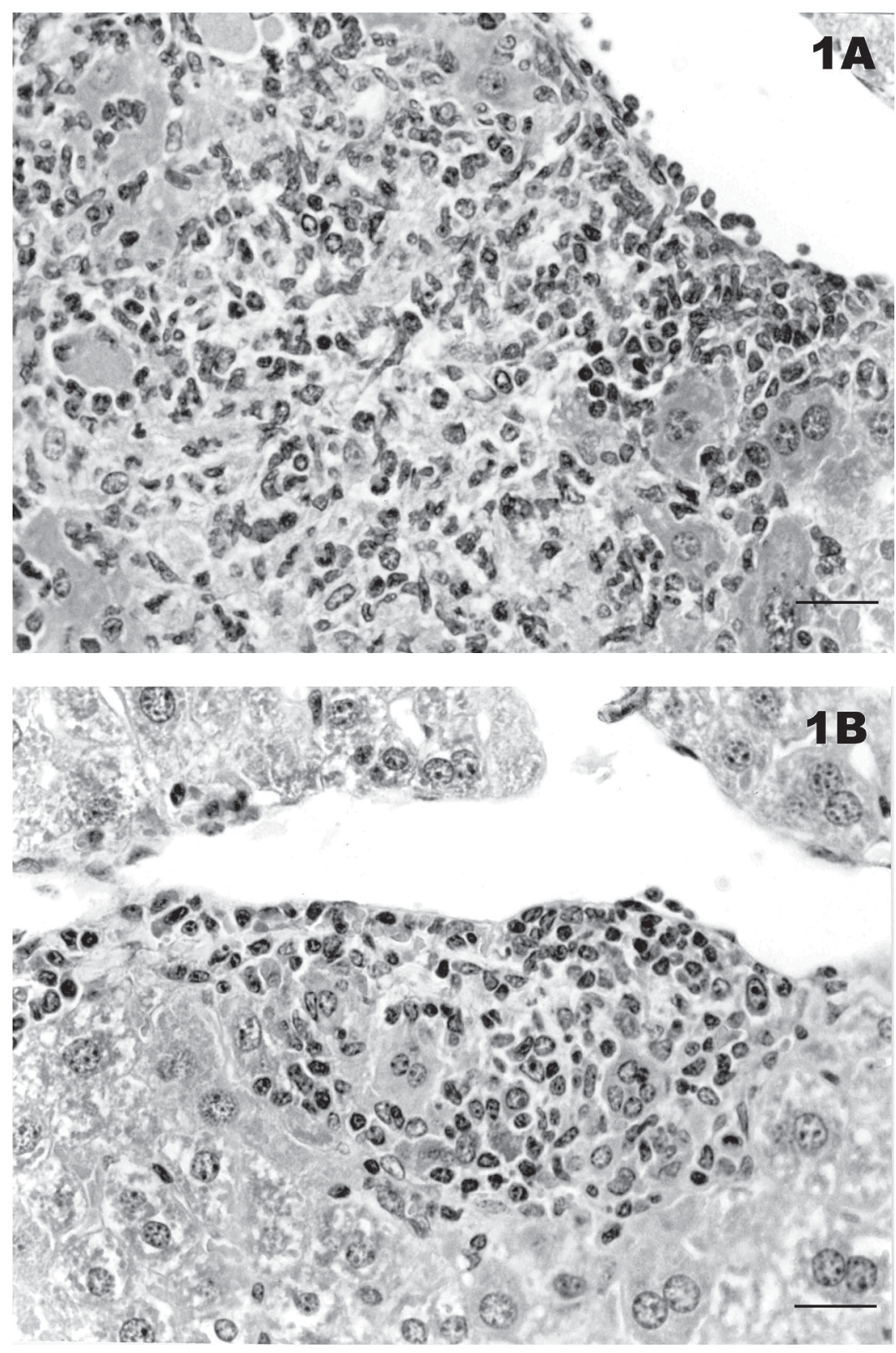

Figure 1. Histologic sections from the liver of germ-free mice infected with Helicobacter trogontum. A, Illustration of an inflammatory infiltrate with mononuclear and polymorphonuclear cells and necrosis of a 6-month-infected mouse, and $B$, a focus of mononuclear cells in a 12-month-infected animal (hematoxylin-eosin; 400X). Bar $=25 \mu \mathrm{m}$. 
The liver of the 18-month group also presented infiltrates of mononuclear cells, though more discrete ones. Differently from the $H$. hepaticus infection, in the H. trogontum model, liver lesions did not progress to fibrosis or cirrhosis. Macroscopic lesions were not detected in the liver of infected animals even when the histologic changes were intense.

Although we could not isolate the bacterium from the liver of the test animals, the results suggest that $H$. trogontum is responsible for the hepatic inflammatory response since the only difference between control and test animals was the presence of $H$. trogontum in the bowel of the latter. Also, the histologic hepatic pattern observed was similar to those caused by the presence of Helicobacter species already detected in liver tissue such as $H$. canis in dogs and $H$. hepaticus and $H$. bilis in mice $(17,18)$.

The fact that $H$. trogontum has already been seen free in the cytoplasm of enterocytes of germ-free animals inoculated with the bacterium (19) suggests the idea that $H$. trogontum may have the ability to translocate and gain access to the liver of the animals. If this is true, the absence of the microorganism in the liver reported here may only reflect a methodologic failure to cultivate $H$. trogontum from this site. Failure to isolate enterohepatic Helicobacter from the liver has also been reported for some mouse strains infected with $H$. hepaticus, such as $\mathrm{A} / \mathrm{JCr}$ mice (19). Several investigators have been trying to explain this result by a possible difference in culture requirement for strains that colonize the liver or by the scarce distribution of the bacterium in the hepatic parenchyma $(2,6,20)$.

Another possibility that cannot be ruled out is that the bacterium can produce a toxic factor in the intestine that affects the integrity of the liver. It has been shown that $H$. hepaticus produces a toxic substance that causes a cytopathic effect in a mouse liver cell line (20). It would be desirable to find out if $H$. trogontum is capable of producing a hepatotoxic substance and also to optimize culture techniques or to develop more sensitive methods for its detection in the liver in order to facilitate further investigation on the matter.

Infection with enterohepatic Helicobacter, such as $H$. hepaticus and $H$. bilis in mice, represents a confounding factor in the interpretation of animal bioassays, especially those evaluating liver carcinogenicity. Attention must also be paid to indigenous Helicobacter of laboratory rats such as $H$. trogontum because of its potential to elicit hepatitis in its natural host.

In conclusion, we demonstrated that another Helicobacter species is associated with liver lesions in mice. This result, together with the increasing number of related reports in the literature, reinforces the possible role of Helicobacter infection in the pathogenesis of hepatobiliary diseases in both animals and man.

\section{References}

1. Graham DY \& Guo MF (1993). Helicobacter pylori: current status. Gastroenterology, 105: 279-282.

2. Solnick JV \& Schauer DB (2001). Emergence of diverse Helicobacter species in the pathogenesis of gastric and enterohepatic disease. Clinical Microbiology Reviews, 14: 59-97.

3. Fox JG, Dewhirst FE, Tully JG, Paster BJ, Yan L, Taylor NS, Collins MF, Corelick PL \& Ward JM (1994). Helicobacter hepaticus sp. nov., a microaerophilic bacterium isolated from livers and intestinal mucosa scrapings from mice. Journal of Clinical Microbiology, 32: 1238-1245.

4. Fox JG, Yan LL, Dewhirst FE, Paster BJ, Shames B, Murphy JC,
Hayward A, Belcher JC \& Mendes EN (1995). Helicobacter bilis sp. nov., a novel Helicobacter isolated from bile, livers, and intestines of aged, inbred mouse strains. Journal of Clinical Microbiology, 33 : 445-454.

5. Mendes EN, Queiroz DMM, Dewhirst FE, Paster BJ, Moura SB \& Fox JG (1996). Helicobacter trogontum sp. nov., isolated from the rat intestine. International Journal of Systematic Bacteriology, 46: 916-921.

6. Groote D, Ducatelle R \& Haesebrouck F (2000). Helicobacters of possible zoonotic origin: a review. Acta Gastroenterologica Belgica, 63: 380-387. 
7. Ward JM, Fox JG, Anver MR et al. (1994). Chronic active hepatitis and associated liver tumors in mice caused by a persistent bacterial infection with a novel Helicobacter species. Journal of the National Cancer Institute, 86: 1222-1227.

8. Shames B, Fox JG, Dewhirst F, Yan L, Shen Z \& Taylor NS (1995). Identification of widespread Helicobacter hepaticus infection in feces in commercial mouse colonies by culture and PCR assay. Journal of Clinical Microbiology, 33: 2968-2972.

9. Fox JG, Li W, Yan L, Cahill RJ, Hurley R, Lewis R \& Murphy JC (1996). Chronic proliferative hepatitis in A/JCr mice associated with persistent Helicobacter hepaticus infection: a model of helicobacterinduced carcinogenesis. Infection and Immunity, 64: 1548-1558.

10. Hailey JR, Haseman JK, Bucher JR, Radovsky AE, Malarkey DE, Miller RT, Nyska A \& Maronpot RR (1998). Impact of Helicobacter hepaticus infection in B6C3F1 mice from twelve national toxicology program two-year carcinogenesis studies. Toxicologic Pathology, 26: 602-611.

11. Moura SB, Mendes EN, Queiroz DMM, Nicoli JR, Cabral MMDA, Magalhães PP, Rocha GA \& Vieira EC (1999). Microbiological and histological study of the gastrointestinal tract of germ-free mice infected with Helicobacter trogontum. Research in Microbiology, 150: 205-212.

12. Queiroz DMM, Mendes EN \& Rocha GA (1987). Indicator medium for isolation of Campylobacter pylori. Journal of Clinical Microbiology, 25: 2378-2379.

13. Carvalho AST, Queiroz DMM, Mendes EN, Rocha GA \& Penna FJ (1991). Diagnosis and distribution of Helicobacter pylori in the gas- tric mucosa of asymptomatic children. Brazilian Journal of Medical and Biological Research, 24: 163-166.

14. Ward JM, Anver MR, Haines DC, Melborn JF, Gorelick P, Yan L \& Fox JG (1996). Inflammatory large bowel disease in immunodeficient mice naturally infected with Helicobacter hepaticus. Laboratory Animal Science, 46: 15-20.

15. Shomer NH, Dangler CA, Schrenzel MD \& Fox JG (1997). Helicobacter bilis-induced inflammatory bowel disease in SCID mice with defined flora. Infection and Immunity, 65: 4858-4864.

16. Gayotto LCC, Alves VAF \& Mello EF (2000). Fígado e vias biliares. In: Brasileiro Filho G (Editor), Bogliolo Patologia. Editora Guanabara Koogan SA, Rio de Janeiro, RJ, Brazil, 643-699.

17. Fox JG, Yan L, Shames B, Campbell J, Murphy JC \& Li X (1996). Persistent hepatitis and enterocolitis in germfree mice infected with Helicobacter hepaticus. Infection and Immunity, 64: 36733681.

18. Fox JG, Drolet R, Higgins R, Messier S, Yan L, Coleman BE, Paster BJ \& Dewhirst FE (1996). Helicobacter canis isolated from a dog liver with multifocal necrotizing hepatitis. Journal of Clinical Microbiology, 34: 2479-2482.

19. Moura SB, Mendes EN, Queiroz DMM, Camargos ER, Fonseca MEF, Rocha GA \& Nicoli JR (1998). Ultrastructure of Helicobacter trogontum in culture and in the gastrointestinal tract of gnotobiotic mice. Journal of Medical Microbiology, 47: 513-520.

20. Taylor NS, Fox JG \& Yan L (1995). In-vitro hepatotoxic factor in Helicobacter hepaticus, H. pylori and other Helicobacter species. Journal of Medical Microbiology, 42: 48-52. 